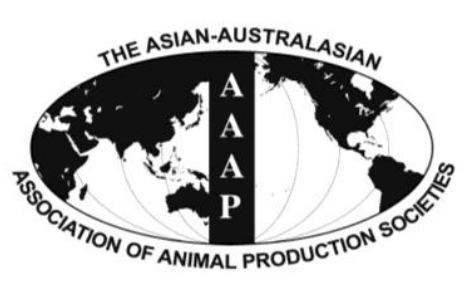

Open Access

Asian Australas. J. Anim. Sci.

Vol. 27 , No. 7 : $974-980$ July 2014

http://dx.doi.org/10.5713/ajas.2013.13383

\author{
www.ajas.info
}

pISSN 1011-2367 elSSN 1976-5517

\title{
Effects of Water Restriction on the Growth Performance, Carcass Characteristics and Organ Weights of Naked Neck and Ovambo Chickens of Southern Africa
}

\author{
N. Chikumba and M. Chimonyo* \\ School of Agricultural, Earth and Environmental Sciences, University of KwaZulu-Natal, \\ P. Bag X01, Scottsville 3209, Pietermaritzburg, South Africa
}

\begin{abstract}
In semi-arid areas of Southern Africa, dehydration can compromise the performance and welfare of local chickens, particularly during the growing period when confinement is curtailed and birds are left to scavenge for feed and water. The effect of water restriction on the growth performance was compared in Naked Neck (NNK) and Ovambo (OVB) chickens that are predominant in Southern Africa. A total of 54 eight-wk-old pullets each of NNK and OVB chickens with an initial average weight of $641 \pm 10 \mathrm{~g} / \mathrm{bird}$ were randomly assigned to three water intake treatments, each having six birds for $8 \mathrm{wk}$. The water restriction treatments were $a d$ libitum, $70 \%$ of ad libitum and $40 \%$ of ad libitum intake. Nine experimental pens with a floor space of $3.3 \mathrm{~m}^{2}$ per strain were used. The pens were housed in an open-sided house with cement floor deep littered with a $20 \mathrm{~cm}$ layer of untreated wood shavings. Feed was provided ad libitum. Average daily water intake (ADWI), BW at 16 weeks of age (FBW), ADG, ADFI, feed conversion ratio (FCR) and water to feed ratios (WFR) were determined. Ovambo chickens had superior $(\mathrm{p}<0.05)$ FBW, ADG and ADWI than NNK chickens. Body weight of birds at 16 weeks of age, ADG, ADFI, ADWI, and WFR declined progressively $(\mathrm{p}<0.05)$ with increasing severity of water restriction while FCR values increased $(\mathrm{p}<0.05)$ as the severity of water restriction increased. Naked Neck chickens had better FCR at the $40 \%$ of ad libitum water intake level than Ovambo chickens. The dressing percentage per bird was higher in water restricted birds than those on ad libitum water consumption, irrespective of strain. Heart weight was significantly lower in birds on $40 \%$ of ad libitum water intake than those on ad libitum and $70 \%$ of ad libitum water intake, respectively. In conclusion, NNK chickens performed better than OVB chickens under conditions of water restriction and would be ideal to raise for meat and egg production in locations where water shortages are a major challenge. (Key Words: Chickens, Ovambo, Feed Intake, Growth Performance, Water Restriction, Semi-arid Areas)
\end{abstract}

\section{INTRODUCTION}

The Ovambo (OVB) and Naked Neck (NNK) chickens are closely associated with rural livelihoods in Southern Africa where they are used to meet nutritional (meat and eggs) and economic needs of households (Mapiye et al., 2008). The chickens also have social, cultural and symbolic roles that transcend their practical use as food or commodities. Birds are often given away as gifts, sacrificed to ancestors and divinities, or consumed as part of ritual and

\footnotetext{
* Corresponding Author: M. Chimonyo. Tel: +27-33-260-5477, Fax:+27-33-260-5067, E-mail: chimonyo@ukzn.ac.za Submitted Jul. 3, 2013; Revised Oct. 7, 2013; Accepted Jan. 7, 2014
}

secular celebrations, thereby strengthening important social bonds (Aklilu et al., 2007).

Ovambo chickens are a small but aggressive, dualpurpose, agile dark coloured breed, thought to have originated from the northern part of Namibia and Ovamboland (van Marle-Koster and Nel, 2000). Sexual maturity is attained at $143 \mathrm{~d}$ with males weighing about $2.16 \mathrm{~kg}$ and females $1.54 \mathrm{~kg}$. The NNK chickens are a widely distributed, multi-coloured, relatively light-weight breed kept for meat and eggs for home consumption. Naked Neck chickens reach sexual maturity at $155 \mathrm{~d}$ of age, with males weighing about $1.95 \mathrm{~kg}$ and females $1.4 \mathrm{~kg}$. Naked Neck chickens possess better post weaning $(>12$ weeks of age) heat tolerance than OVB chickens due to the presence

Copyright $@ 2014$ by Asian-Australasian Journal of Animal Sciences This is an open-access article distributed under the terms of the Creative Commons Attribution Non-Commercial License (http://creativecommons.org/licenses/by-nc/3.0/), which permits unrestricted non-commercial use, distribution, and reproduction in any medium, provided the original work is properly cited. 
of a major gene that causes reduced plumage cover (Cahaner et al., 1993). Reduced plumage is effective when temperatures are high and birds have to dissipate excess heat (Deeb and Cahaner, 2001). Adaptation of NNK chickens to water restriction has, however, not been established. Haematological and serum biochemical responses of these strains to water restriction have been reported earlier (Chikumba et al., 2013).

Approximately $80 \%$ indigenous chicken producers in Southern Africa live in fragile and marginal environments where there is lack of adequate potable water for both human and livestock consumption (Swatson, 2003). The situation is worsened in the hot dry periods of the year when availability of water and succulent scavenging resources is low. In addition, Mwale and Masika (2009) showed that about $60 \%$ of indigenous chicken producers in rural areas do not to offer water to recently weaned freeranging chickens, trusting their ability to scavenge for water. The chickens usually subsist on unpalatable, detergent tainted waste-water from bathrooms and kitchens. It is crucial to evaluate the effect of restricted water intake during the growing period of local chickens as it is likely to reduce subsequent hen-day egg production and egg (Saengchan et al., 2008). Understanding the effects of restricted water intake on the growth performance of chicken strains kept by smallholder poultry producers is not only crucial in elucidating the mechanisms of adaptation to water stress but in identifying drought-tolerant strains for use in the future and enhancement of food security in drought prone areas.

The objective of the study was, therefore, to compare the effects of water restriction on BW gains, feed intake, feed conversion ratio and water to feed ratios of NNK and OVB chickens. It was hypothesized that NNK chickens have a greater ability to withstand higher levels of water restriction than OVB chickens.

\section{MATERIALS AND METHODS}

\section{Study site and ethical aspects of the study}

The study was conducted between January and March 2012 at Cedara College of Agriculture, which is located in the upland savanna zone on latitude $29.53^{\circ} \mathrm{S}$ and longitude $30.27^{\circ} \mathrm{E}$ at altitude $613 \mathrm{~m}$. The minimum, maximum and average temperature and relative humidity during the experimental weeks are summarized in Table 1. The average environmental temperature was $22.3^{\circ} \mathrm{C}$ and relative humidity was moderate at an average of $65.8 \%$. Care and use of chicks were compliant with internationally accepted standards for welfare and ethics of research animals (Austin et al., 2004) and were specifically approved by the University of KwaZulu-Natal Animal Ethics Research
Table 1. Average minimum and maximum temperature and average relative humidity from 9 to 16 weeks of age of the trial

\begin{tabular}{ccccc}
\hline \multirow{2}{*}{ Week } & \multicolumn{3}{c}{ Temperature $\left({ }^{\circ} \mathrm{C}\right)$} & $\begin{array}{c}\text { Relative } \\
\text { humidity }(\%)\end{array}$ \\
\cline { 2 - 4 } & Mean & Min. & Max. & 76.6 \\
\hline 9 & 22.4 & 16.4 & 28.3 & 71.8 \\
10 & 23.5 & 18.0 & 29.0 & 75.6 \\
11 & 22.9 & 18.6 & 27.1 & 61.3 \\
12 & 24.4 & 19.3 & 29.4 & 61.8 \\
13 & 25.4 & 18.1 & 32.6 & 60.5 \\
14 & 21.8 & 16.1 & 27.4 & 63.0 \\
15 & 20.5 & 14.3 & 26.7 & 56.3 \\
16 & 17.9 & 12.1 & 23.7 & \\
\hline
\end{tabular}

Committee (Reference number: 048/12/Animal).

\section{Birds, treatments and management}

A total of 250 day-old chicks each of Ovambo and Naked Neck strains, hatched from parent stock of a conserved population kept at the Agricultural Research Council, Irene, Pretoria, were used in the experiment.

From d 1 to $\mathrm{d} 49$ chicks of each strain were reared in separate $(2 \times 1.5 \mathrm{~m})$ pens in a closed well ventilated poultry house which was $2 \mathrm{~m}$ wide and $3 \mathrm{~m}$ long. Floors were covered with a $15 \mathrm{~cm}$ thick layer of wood shavings. Infrared lamps (75 watt) were used as a source of heat and light. Room temperature was gradually decreased from $32^{\circ} \mathrm{C}$ when the birds were $1 \mathrm{~d}$ old to $21^{\circ} \mathrm{C}$ when $21 \mathrm{~d}$ old by raising the infrared lamps and extending the surrounds of the pens. On account of cold weather, light was provided continuously from infrared lamps because it was necessary to heat the room. A proprietary broiler starter diet (Table 2) was offered ad libitum from tube feeders made of standard gutter materials. Potable tap water was offered ad libitum in $4 \mathrm{~L}$ plastic founts. Birds were vaccinated against Newcastle disease at 10 and $35 \mathrm{~d}$ of age. A foot bath drenched with virucidal chemical was placed at the entrance to the brooding house.

At d 49 of age, the birds were weighed, and 54 females of each strain with bodyweight of $641 \pm 10 \mathrm{~g} / \mathrm{bird}$ were

Table 2. Chemical composition (label values) of commercial broiler starter and grower feeds used in the study ${ }^{1}$

\begin{tabular}{lcc}
\hline Composition & Starter & Grower \\
\hline Crude protein $(\mathrm{g} / \mathrm{kg})$ & 200.00 & 180.00 \\
Metabolisable energy $(\mathrm{MJ} / \mathrm{g})$ & 12.76 & 13.00 \\
$\mathrm{ME} / \mathrm{CP}$ ratio $(\mathrm{MJ} / \mathrm{g})$ & 0.06 & 0.07 \\
Fat $(\mathrm{g} / \mathrm{kg})$ & 25.00 & 25.00 \\
Fibre $(\mathrm{g} / \mathrm{kg})$ & 50.00 & 60.00 \\
Moisture $(\mathrm{g} / \mathrm{kg})$ & 120.00 & 120.00 \\
Calcium $(\mathrm{g} / \mathrm{kg})$ & 12.00 & 12.00 \\
Phosphorus $(\mathrm{g} / \mathrm{kg})$ & 6.00 & 5.50 \\
Lysine $(\mathrm{g} / \mathrm{kg})$ & 12.00 & 10.00 \\
\hline
\end{tabular}

${ }^{1}$ Supplied by Meadow Feeds, Pietermaritzburg, South Africa. 
randomly selected and placed in nine experimental pens. The pens were $230 \mathrm{~cm}$ long, $143 \mathrm{~cm}$ wide and $120 \mathrm{~cm}$ high corresponding to three water restriction treatments replicated three times. Each replicate, represented by a pen, had six birds. The water restriction treatments were ad libitum, $70 \%$ and $40 \%$ of ad libitum intake. Birds were acclimated to the pen environment for $7 \mathrm{~d}$ prior to the experiment. During this period, all birds were allowed water ad libitum and a proprietary grower diet (Table 2) was gradually introduced. Thereafter, and depending on the restriction treatment, water was supplied in one instalment daily at $0900 \mathrm{~h}$ for $8 \mathrm{wk}$ until the birds were $16 \mathrm{wk}$ old. Water restricted birds were given $70 \%$ and $40 \%$ of the amount that the ad libitum group consumed the previous day. When water was offered, water restricted birds drank it all in less than $5 \mathrm{~min}$. Water levels were chosen to represent optimum, moderate and severe water restriction, respectively, which the birds usually encounter under natural conditions (Mupeta et al., 2000). The experimental pens were housed in an open-sided house with cement floor, deep littered with wood shavings. The resulting stocking density was 3.5 birds $/ \mathrm{m}^{2}$. All the birds were fed on the same proprietary finisher pellets until they were 16 wk old. Feed was provided ad libitum and given from tube feeders made of standard gutter materials measuring $30 \mathrm{~cm}$ long $\times 12 \mathrm{~cm}$ wide $\times 9 \mathrm{~cm}$ deep. Wood shavings were changed on a weekly basis and water founts cleaned daily.

\section{Data collection}

Average daily water intake (ADWI) was determined as the difference between water supplied and water refused after 24 h. Daily water intake was corrected for evaporative loss, which was determined using two founts of similar design and capacity placed at random points within the experimental facility. Body weight changes were determined by measuring BW for each bird on a weekly basis starting from wk zero of the experiment. Data of weekly body weights were used to calculate ADG g/bird/d. Feed consumption was measured every wk to establish the ADFI g/bird/d. Feed conversion ratio (FCRg/g) was calculated as the amount of feed consumed per unit of live weight gain. Water to feed ratio (WFR $\mathrm{mL} / \mathrm{g}$ ) was calculated as the proportion of water to feed consumed daily during the experimental period. Mortality was recorded as and when it occurred. At the end of the trial 12 birds from each water restriction treatment i.e 4 birds from each replication, were randomly selected for evaluation of carcass characteristics and internal organ weights. The birds were slaughtered in the early morning $(0800 \mathrm{~h})$. After bleeding, the carcasses were scalded in water at temperatures ranging between $70^{\circ} \mathrm{C}$ and $90^{\circ} \mathrm{C}$. Feathers were plucked manually. The carcasses were then eviscerated and weighed using a digital electronic scale
(Jadever JPS-1050, Micro Precision Calibration Inc, USA). The liver, lungs, heart, kidneys and the gizzard were also collected and weighed. The length of the gastro-intestinal tract from the gizzard was also measured using a flexible tape.

\section{Statistical analysis}

The data were analysed using a mixed model with repeated measurements in time (age) by the MIXED procedure of the SAS (2010). The covariance matrix was chosen using the Akaike information criterion to detect the effects of the main causes of variation (strain, water restriction level and age), as well as their interactions. The model used was:

$$
\begin{aligned}
Y_{i j k l}= & \mu+B_{i}+T_{j}+A_{k}+(B \times T)_{i j}+(B \times A)_{i k} \\
& +(T \times A)_{j k}+(B \times T \times A)_{i j k}+\varepsilon_{i j k l}
\end{aligned}
$$

Where:

$\mathrm{Y}_{\mathrm{ijkl}}=$ response variable $(\mathrm{ADWI}, \mathrm{ADFI}, \mathrm{ADG}, \mathrm{FCR}$, WFR, carcass characteristics and organ weights)

$\mu=$ overall mean

$\mathrm{B}_{\mathrm{i}}=$ effect of the ith strain, with $\mathrm{i}=\mathrm{NNK}$ and OVB;

$\mathrm{T}_{\mathrm{j}}=$ effect of $\mathrm{jth}$ water restriction level, with $\mathrm{j}=a d$ libitum, $70 \%$ and $40 \%$ of ad libitum;

$\mathrm{A}_{\mathrm{k}}=$ age with $\mathrm{k}=9,10 \ldots 16$ weeks;

$(\mathrm{B} \times \mathrm{T})_{\mathrm{ij}}=$ interaction of the ith strain and $\mathrm{jth}$ level of water restriction;

$(\mathrm{B} \times \mathrm{A})_{\mathrm{ik}}=$ interaction of ith strain and kth age of bird;

$(\mathrm{T} \times \mathrm{A})_{\mathrm{jk}}=$ interaction of $\mathrm{jth}$ treatment and kth age of bird;

$(\mathrm{B} \times \mathrm{T} \times \mathrm{A})_{\mathrm{ijk}}=$ interaction of the ith strain, $\mathrm{jth}$ level of water restriction and kth age of bird; and

$\varepsilon_{\mathrm{ijkl}}=$ random error term assumed to be normally and independently distributed with mean 0 and variance equal to $\delta^{2}$.

Least square means were compared using the PDIFF procedure of SAS (2010). Statistical significance was considered at the $5 \%$ level of probability.

\section{RESULTS}

No chick deaths were recorded during the entire experimental period among the different combinations of strains and water restriction levels.

\section{Water intake}

Strain had a significant effect on water intake such that OVB chickens with an ADWI of $113.6 \pm 6.08 \mathrm{~mL} / \mathrm{d}$ drank more $(\mathrm{p}<0.05)$ than NNK chickens with $91.1 \pm 6.08 \mathrm{~mL} / \mathrm{d}$. No significant interaction was observed between strain and water restriction level on this parameter (Table 3). 
Table 3. Performance parameters of Naked Neck and Ovambo chickens raised with or without water restriction

\begin{tabular}{|c|c|c|c|c|c|c|c|c|c|c|}
\hline \multirow{3}{*}{$\begin{array}{l}\text { Performance parameter } \\
\text { (per bird basis) }\end{array}$} & \multicolumn{6}{|c|}{ Strain } & \multirow{3}{*}{$\mathrm{SE}^{1}$} & \multirow{2}{*}{\multicolumn{3}{|c|}{ Anova (p-value) }} \\
\hline & \multicolumn{3}{|c|}{ Naked neck } & \multicolumn{3}{|c|}{ Ovambo } & & & & \\
\hline & Ad lib & $\begin{array}{l}70 \% \text { of } \\
\text { ad lib }\end{array}$ & $\begin{array}{l}40 \% \text { of } \\
\text { ad lib }\end{array}$ & Ad lib & $\begin{array}{l}70 \% \text { of } \\
\text { ad lib }\end{array}$ & $\begin{array}{l}40 \% \text { of } \\
\text { ad lib }\end{array}$ & & Strain & $\mathrm{WRL}^{2}$ & $\begin{array}{r}\text { Strain } \\
\times W R L\end{array}$ \\
\hline Birds (n) & 18 & 18 & 18 & 18 & 18 & 18 & & & & \\
\hline Weight at 16 weeks (g) & $1,595.8$ & $1,334.4$ & $1,037.3$ & $1,278.6$ & $1,528.1$ & $1,824.4$ & 45.39 & 0.001 & 0.001 & 0.86 \\
\hline Average daily gain $(\mathrm{g} / \mathrm{d})$ & 17.3 & 12.5 & 7.7 & 20.6 & 15.1 & 11.6 & 0.77 & 0.002 & 0.001 & 0.69 \\
\hline Average daily feed intake (g/d) & 82.1 & 63.9 & 39.3 & 81.7 & 77.6 & 70.3 & 4.30 & 0.06 & 0.008 & 0.29 \\
\hline Feed conversion ratio & 4.7 & 5.2 & 5.1 & 4.0 & 5.2 & 6.2 & 0.59 & 0.09 & 0.001 & 0.30 \\
\hline Average daily water intake $(\mathrm{mL} / \mathrm{d})$ & 129.9 & 91.2 & 52.0 & 162.5 & 113.5 & 64.9 & 10.5 & 0.02 & 0.001 & 0.66 \\
\hline Water:feed ratio (mL:g) & 1.6 & 1.4 & 0.9 & 2.0 & 1.5 & 0.9 & 0.15 & 0.18 & 0.002 & 0.45 \\
\hline
\end{tabular}

Means within a row followed by different superscript are significantly different $(\mathrm{p}<0.05)$.

${ }^{1} \mathrm{SE}=$ Standard error. ${ }^{2} \mathrm{WRL}=$ Water restriction level.

\section{Body weight at 16 weeks of age}

There were significant differences between strains in the weight of birds at $16 \mathrm{wk}$ of age. Ovambo chickens with average live weight of $1,544 \pm 26.2 \mathrm{~g} / \mathrm{bird}$ were heavier $(\mathrm{p}<0.05)$ than Naked Neck chickens with 1,323 $\pm 26.2 \mathrm{~g} / \mathrm{bird}$. Water restriction also affected the weight of birds at $16 \mathrm{wk}$ of age. The BW of the birds at 16 wk of age declined proportionally as the magnitude of water restriction increased. Body weights were 1,710 $\pm 32.1,1,431 \pm 32.1$ and $1,158 \pm 32.1 \mathrm{~g} / \mathrm{bird}$, for birds on ad libitum, $70 \%$ and $40 \%$ of ad libitum water intake, respectively. Although, no interaction between strain and water restriction level was observed, body weights of NNK chickens on $70 \%$ and $40 \%$ of ad libitum water intake were $16.6 \%$ and $34.1 \%$ lower $(\mathrm{p}<0.05)$ than that of those on ad libitum water intake, respectively. Similarly, the BW of OVB chickens on $70 \%$ and $40 \%$ of ad libitum water intake were $16.8 \%$ and $28.7 \%$ lower $(\mathrm{p}<0.05)$ than those of birds on ad libitum water intake, respectively (Table 3).

\section{Average daily gain}

There was a significant effect of strain on ADG during the study period. The OVB chickens had higher $(\mathrm{p}<0.05)$ ADG $(15.8 \pm 0.45 \mathrm{~g} / \mathrm{bird} / \mathrm{d})$ than NNK chickens $(12.5 \pm 0.45$ $\mathrm{g} / \mathrm{bird} / \mathrm{d})$. The ADG was also influenced $(\mathrm{p}<0.05)$ by water restriction level such that birds on $40 \%$ of ad libitum water intake had the lowest $(\mathrm{p}<0.05)$ gains $(9.6 \pm 0.55 \mathrm{~g} / \mathrm{bird} / \mathrm{d})$ followed $(\mathrm{p}<0.05)$ by those that received $70 \%$ of ad libitum $(13.8 \pm 0.55 \mathrm{~g} / \mathrm{bird} / \mathrm{d})$ while those on ad libitum $(19.0 \pm 0.55$ $\mathrm{g} / \mathrm{bird} / \mathrm{d})$ water intake had the highest $(\mathrm{p}<0.05)$ ADG. No significant interaction between strain and water restriction level was observed for ADG (Table 3).

\section{Average daily feed intake}

No significant effect of strain was observed on ADFI. Water restriction level, however, affected ADFI. Birds subjected to ad libitum water intake had the highest $(\mathrm{p}<0.05)$ ADFI $(81.9 \pm 3.04 \mathrm{~g} / \mathrm{bird} / \mathrm{d})$, followed by those on $70 \%$ of $\mathrm{ad}$ libitum $(70.7 \pm 3.04 \mathrm{~g} / \mathrm{bird} / \mathrm{d})$ and $40 \%$ of ad libitum
$(65.9 \pm 3.04 \mathrm{~g} / \mathrm{bird} / \mathrm{d})$ water intake, which were not significantly different $(\mathrm{p}>0.05)$. Even though no significant interaction was observed between strain and water restriction level on feed intake, feed consumption of NNK chickens on ad libitum water consumption was $52 \%$ and $8 \%$ higher than that of birds given water at $40 \%$ and $70 \%$ of ad libitum, respectively, while for OVB it was $23 \%$ and $8 \%$ higher, respectively (Table 3 ).

\section{Feed conversion ratio}

Water restriction level had a significant effect $(\mathrm{p}<0.05)$ on the FCR. Birds on $40 \%$ of ad libitum water intake had the highest $(\mathrm{p}<0.05)$ FCR of $7.2 \pm 0.41 \mathrm{~g} / \mathrm{g}$, followed by those on $70 \%$ of ad libitum water intake with $5.2 \pm 0.41 \mathrm{~g} / \mathrm{g}$, while those on ad libitum water intake with $4.4 \pm 0.41 \mathrm{~g} / \mathrm{g}$ had the lowest. Strain of chicken had no effect on FCR. Although the interaction between strain and water restriction level was not significant, NNK chickens subjected to $40 \%$ of ad libitum water intake had a lower FCR compared to OVB chickens (Table 3).

\section{Water:feed ratio}

Strain of chicken did not affect the average WFR, but there was a progressive decline due to water restriction. The highest $(\mathrm{p}<0.05)$ WFR was observed in birds on ad libitum $(1.8 \pm 0.11 \mathrm{~mL} / \mathrm{g})$ water followed by those on $70 \%$ of $\mathrm{ad}$ libitum $(1.5 \pm 0.11 \mathrm{~mL} / \mathrm{g})$ while those on the $40 \%$ of $\mathrm{ad}$ libitum $(0.9 \pm 0.11 \mathrm{~mL} / \mathrm{g})$ water intake had the lowest. There was no interaction between strain and water restriction level on WFR (Table 3).

\section{Carcass characteristics and organ weights}

Strain of chicken had no effect on the weight of organs. However, there was a significant reduction in the dressed weight and liver, lung and heart weights due to water restriction. Birds on the $40 \%$ of ad libitum water intake had the lowest $(824 \pm 47.7 \mathrm{~g} / \mathrm{bird})$ dressed weights compared to those on $70 \%$ of ad libitum $(991 \pm 47.7 \mathrm{~g} / \mathrm{bird})$ and $\mathrm{ad}$ libitum water intake $(1,017 \pm 47.7 \mathrm{~g} / \mathrm{bird})$, which were not 
significantly different. Heart weight was significantly lower in birds on the $40 \%$ of ad libitum water intake $(8 \pm 0.4 \mathrm{~g} / \mathrm{bird})$ than those on the $70 \%$ of ad libitum $(10 \pm 0.4 \mathrm{~g} / \mathrm{bird})$ and $\mathrm{ad}$ libitum water intake $(10 \pm 0.4 \mathrm{~g} / \mathrm{bird})$, which were also similar. The highest liver weights were recorded in birds on ad libitum ( $35 \pm 1.9 \mathrm{~g} / \mathrm{bird})$ followed by those on $70 \%$ of $\mathrm{ad}$ libitum $(30 \pm 1.9 \mathrm{~g} / \mathrm{bird})$ and $40 \%$ of ad libitum $(27 \pm 1.9$ $\mathrm{g} / \mathrm{bird}$ ), in that order. A similar trend was observed for lung weight where birds on the $40 \%$ of ad libitum had the lowest

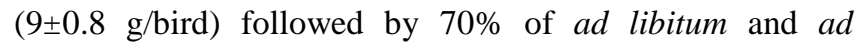
libitum water intake each with $11 \pm 0.8 \mathrm{~g} / \mathrm{bird}$. There was no significant interaction between strain and water restriction level for all the carcass and internal organ parameters measured (Table 4).

\section{DISCUSSION}

In the present study, the lower water intake of NNK chickens on ad libitum water intake could be a reflection of either lower water requirements, a greater dependence on metabolic water to maintain hydrational homeostasis or a higher capability of budgeting body water more economically than OVB chickens. Similar differences in efficiency of water utilization among chicken strains were reported by Ahmed and Alamer (2011), who reported that Saudi local chickens had lower water requirements than fast growing Hisex commercial layers.

At $40 \%$ water restriction, the decline in body weight reflected a superiority of NNK over OVB chickens in water expenditure and utilization, since water consumption of the former was lower than that of the latter. It could be postulated that NNK chickens were able to budget their water balance efficiently than OVB chickens. Strain differences in body weight loss were previously reported by Arad (1982) who noted significantly higher rates of weight loss in commercial Leghorns compared to native chickens during water deprivation under hot conditions. The decline in body weight of birds fed at $70 \%$ of ad libitum was comparable with results of Abdelsamie and Yadiwilo (1981) who reported a drop of $18 \%$ in body weight in broilers maintained on a $25 \%$ water restriction under hot conditions.

The finding that there was a progressive decline in ADFI with increasing severity of water restriction concurs with previous studies that showed that birds reduce their feed intake as an important adaptive strategy to preserve body water by reducing faecal water loss together with reducing body heat increment (Pires et al., 2007; Viola et al., 2009). Our results, however, contradict findings of Ahmed and Alamer (2011), who reported no significant effect of water restriction on feed intake in local Saudi breed layers subjected to $40 \%$ water restriction. Kellerup et al. (1965) also noted no significant decrease in food consumption when water was restricted in broilers. The high feed intake observed by these authors during water deficiency could also be an important adaptive mechanism employed by these chickens to reduce the adverse impact of water scarcity.

The high FCR of OVB chickens subjected to water restriction compared to NNK chickens has important economic implications as the feed consumed reduced ADG significantly compared to birds that drank water ad libitum. The better FCR of NNK than OVB chickens under water restriction is consistent with findings of van Marle-Köster and Casey (2001), who found that the former had better FCR and higher growth rates than most indigenous chicken strains found in South Africa under extensive production conditions that characterise most communal areas where they are normally kept.

The WFR of OVB chickens on ad libitum intake were within the normal reference range of 2:1 (NRC, 1994),

Table 4. Carcass and internal organ weights of 16 week old female Naked Neck and Ovambo chickens raised with or without water restriction

\begin{tabular}{|c|c|c|c|c|c|c|c|c|c|c|}
\hline \multirow{3}{*}{$\begin{array}{l}\text { Carcass } \\
\text { and viscera parameter } \\
\text { (per bird) }\end{array}$} & \multicolumn{6}{|c|}{ Strain } & \multirow{3}{*}{$\pm \mathrm{SE}^{1}$} & \multirow{2}{*}{\multicolumn{3}{|c|}{ Anova (p-value) }} \\
\hline & \multicolumn{3}{|c|}{ Naked neck } & \multicolumn{3}{|c|}{ Ovambo } & & & & \\
\hline & Ad lib & $\begin{array}{l}70 \% \text { of } \\
a d l i b\end{array}$ & $\begin{array}{l}40 \% \text { of } \\
\text { ad lib }\end{array}$ & Ad lib & $\begin{array}{c}70 \% \text { of } a d \\
l i b\end{array}$ & $\begin{array}{c}40 \% \text { of } \\
\text { ad lib }\end{array}$ & & Strain & $\mathrm{WRL}^{2}$ & $\begin{array}{c}\text { Strain } \times \\
\text { WRL }\end{array}$ \\
\hline Birds (n) & 12 & 12 & 12 & 12 & 12 & 12 & & & & \\
\hline Cold dressed mass (g) & $1,050.1$ & 994.0 & 827.3 & 965.9 & 940.8 & 886.4 & 67.48 & 0.66 & 0.10 & 0.49 \\
\hline Dressing percentage & 65.2 & 74.6 & 76.9 & 53.8 & 63.6 & 68.8 & 5.50 & 0.05 & 0.06 & 0.94 \\
\hline Liver $(\mathrm{g})$ & 34.4 & 31.8 & 28.8 & 34.5 & 27.5 & 26.7 & 2.97 & 0.42 & 0.08 & 0.72 \\
\hline Lung (g) & 9.3 & 11.7 & 9.0 & 11.4 & 10.3 & 9.3 & 1.22 & 0.79 & 0.34 & 0.32 \\
\hline Heart (g) & 10.0 & 10.1 & 8.7 & 10.0 & 9.4 & 8.2 & 0.56 & 0.40 & 0.04 & 0.73 \\
\hline Kidney (g) & 10.5 & 10.1 & 8.8 & 10.2 & 10.1 & 8.4 & 0.96 & 0.78 & 0.19 & 0.98 \\
\hline Gizzard (g) & 41.7 & 40.1 & 33.3 & 39.8 & 35.8 & 33.7 & 3.26 & 0.50 & 0.11 & 0.74 \\
\hline GIT (cm) & 127.8 & 127.9 & 129.5 & 121.0 & 120.9 & 132.0 & 6.19 & 0.49 & 0.51 & 0.64 \\
\hline
\end{tabular}

Means within a row followed by different superscript are significantly different $(\mathrm{p}<0.05)$.

${ }^{1} \mathrm{SE}=$ Standard error. ${ }^{2} \mathrm{WRL}=$ Water restriction level. 
while those of NNK chickens were lower than the normal reference range. Naked Neck chickens appear to have lower water requirements than OVB chickens for the same amount of feed consumed. In agreement with the present study, Ahmed and Alamer (2011) determined that the WFR of Saudi local chicken was lower than those of a commercial layer strain. The observed WFR, however, contradicts with Miller et al. (1988). Birds are expected to voluntarily reduce their feed intake when the quantity of water is restricted in order to conserve body water. It is, however, worth noting that water consumption by birds is influenced by many factors, including, the age (Leeson and Summers, 2008), genotype (Ahmed and Alamer, 2011), sex (Ziaei et al., 2007), stocking density (Feddes et al., 2002), health and welfare (Manning et al., 2007), ambient temperature (Belay et al., 1993), quality of feed and behavioural patterns such as polydipsia (Proudman and Opel, 1981).

The significant effect of water restriction on dressing percentage could be attributed to differences in live-weight among the different water restriction levels. Saleh (1992) reported a strong relationship between body weight and carcass weight $(\mathrm{r}=0.98)$ and between carcass weight and dressing percentage $(r=0.33)$. The high dressing percent of water restricted birds could also be attributed to the fact that water restriction elicited a stronger water saving response that led to attenuation of body water losses, resulting in higher dressing percentage compared to birds on ad libitum water intake. Similar observations were made in Saudi local chickens (Ahmed and Alamer, 2011). The low heart weight of birds fed water at $40 \%$ of ad libitum is consistent with results reported by Burh et al. (1998) in chicks submitted to food and water deprivation, according to which heart weight decreased with increasing water deprivation. In contrast, Viola et al. (2009) observed an increase in relative heart weight in broilers restricted of water for three weeks. The increase in heart weight was attributed to higher blood viscocity caused by water restriction.

\section{CONCLUSIONS}

It can be concluded that under thermoneutral conditions and up to $16 \mathrm{wk}$ of age, Naked Neck chickens consume less water than Ovambo chickens, which could be a reflection of their lower water requirements, greater dependence on metabolic water or unsual capability to budget water more economically. The Ovambo had higher weight gain, feed intake and FCR at moderate levels of water restriction, but NNK performed better at the most severe water restriction level. The low water requirements coupled with high FCR of Naked Neck chickens at the most severe water restriction level makes them ideal to keep for meat production in locations where access to water is limited.

\section{ACKNOWLEDGEMENT}

The authors acknowledge the National Research Fund (NRF), South Africa for funding the study and the Cedara College of Agriculture Poultry Unit for the technical assistance rendered.

\section{REFERENCES}

Abdelsamie, R. E. and F. Yadiwilo. 1981. Water consumption and effects of water restriction on performance of broilers in the tropics. Br. Poult. Sci. 22:423-429.

Ahmed, A. S. and M. A. Alamer. 2011. Effect of short-term water restriction on body weight, egg production, and immune response of local and commercial layers in the late phase of production. Asian Australas. J. Anim. Sci. 24:825-833.

Aklilu, H. A., C. J. M. Almekinders, H. M. J. Udo, and A. J. van der Zijpp. 2007. Village poultry consumption and marketing in relation to gender, religious festivals and market access. Trop. Anim. Health Prod. 39:165-168.

Arad, Z. 1982. Effect of water deprivation and heat exposure on body weight loss and drinking capacity in four breeds of fowl (Gallus Domesticus). Comp. Biochem. Physiol. Part A Physiol. 73A:297-299.

Austin, J. C., D. N. du Toit, P. L. Fraser, D. Mansfield, A. Macleod, J. S. J. Odendaal, and J. Seier. 2004. Guidelines on ethics for medical research: Use of animals in research and training. South African Medical Research Council. pp. 1-53.

Belay, T. and R. G. Teeter. 1993. Broiler water balance and thermobalance during thermoneutral and high ambienttemperature exposure. Poult. Sci. 72:116-124.

Buhr, R. J., J. K. Northcutt, and C. E. Lyon. 1998. Influence of time off feed on broiler viscera weight, diameter and shear. Poult. Sci. 77:758-764.

Cahaner, A., N. Deeb, and M. Gutman. 1993. The effects of the plumage-reducing Naked Neck $(\mathrm{Na})$ gene on the performance of fast growing broilers at normal and high ambient temperature. Poult. Sci. 72:767-775.

Chikumba, N., H. Swatson, and M. Chimonyo. 2013. Haematological and serum biochemical responses of chickens to hydric stress. Animal 7:1517-1522.

Deeb, N. and A. Cahaner. 2001. Genotype-by-environment interaction with broiler genotypes differing in growth rate 1 . The effects of high ambient temperatures and naked neck genotype on lines differing in genetic background. Poult. Sci. 80:695-702.

Feddes, J. J. R., E. J. Emmanuel and M. J. Zuidhof. 2002. Broiler performance, body weight variance, feed and water intake, and carcass quality at different stocking densities. Poult. Sci. 81: 774-779.

Kellerup, S. U., J. E. Parker, and G. H. Arscott. 1965. Effect of restricted water consumption on broilers chickens. Poult. Sci. 44:79-83.

Leeson, S. and J. D. V. Summers. 2000. Broiler and breeder production:nutrition and feeding (Guelph University Books)

Manning, L., S. A. Chadd, and R. N. Baines. 2007. Water consumption in broiler chicken: A welfare indicator. World's 
Poult. Sci. J. 63:63-71.

Mapiye, C., M. Mwale, J. F. Mupangwa, M. Chimonyo, R. Foti, and M. J. Mutenje. 2008. A research review of village chicken production constraints and opportunities in Zimbabwe. Asian Australas. J. Anim. Sci. 21:1680-1688.

Miller, L., G. W. Morgan, and J. W. Deaton. 1988. Cyclic watering of broiler cockerels. Poult. Sci. 67:378-383.

Mupeta, B., J. Wood, F. Mandonga, and J. Mhlanga. 2000. A comparison of the performance of village chickens, under improved feed management, with the performance of hybrid chickens in tropical Zimbabwe. In: Sustaining livestock in challenging dry season environments: Strategies for smallscale livestock farmers (Eds. T. Smith and S. H. Godfrey). Proceedings of the third workshop on livestock production programme projects. 2000 September 26-28; Ingwe lodge and ICRISAT, Matobo, Zimbabwe.

Mwale, M. and P. J. Masika. 2009. Ethno-veterinary control of parasites, management and role of village chickens in rural households of Centane district in the Eastern Cape, South Africa. Trop. Anim. Health Prod. 41:1685-1693.

NRC (National Research Council). 1994. Nutrient Requirements of Poultry. 8. revised Edn. National Academy Press, Washington, DC. p. 155.

Pires, D. L., E. B. Malheiros, and I. C. Boleli. 2007. Influence of sex, age, and fasting on blood parameters and bursa, spleen and yolk sac weights of broiler chicks. Braz. J. Poult. Sci. 9: 221-228.

Proudman, J. A. and H. Opel. 1981. Effect of feed or water restriction on basal and TRH-stimulated growth hormone secretion in the growing turkey poult. Poult. Sci. 60:659-667.
Saengchan, Y., N. Gongruttananum, R. Chotesangasa, and P. Tumkiratiwong. 2008. Effects of restriction of water consumption on egg and eggshell quality, fecal moisture contents, hematology and reproductive performance in laying hens. Proceedings of the 46th Kasetsart University Annual Conference, Kasetsart. Anim. Vet. Med. 195-204.

Saleh, G. A. M.1992. Comparative Studies on the Performance of Some Broiler Hybrids under Certain Feeding System. PhD Thesis, Animal Production Department, Minia University, Egypt.

SAS. 2010. SAS User Guide: Release 9.2. SAS Institute Inc., Cary, North Carolina, USA.

Swatson, H. K. 2003. The small holder poultry development workshop: The Potential of smallholder indigenous poultry production in improving the livelihoods and food security of rural households. Proceedings of Nature and Development Group of Africa in Action for Sustainable Rural Development, 2003 October 28-31; University of Natal, Pietermaritzburg, South Africa.

Van Marle-Köster, E. and L. H. Nel. 2000. Genetic characterization of native southern African chicken populations: Evaluation and selection of polymorphic microsatellite markers. S. Afr. J. Anim. Sci. 30:1-6.

Van Marle-Köster, E. and N. H. Casey. 2001. Phenotypic characterisation of native chicken lines in South Africa. Anim. Genet. Resour. Inf. 29:71-78.

Viola, T. H., A. M. Ribeiro, A. M. Junior, and E. S.Viola. 2009. Influence of water restriction on the performance and organ development of young broilers. R. Bras. Zootec. 38:323-327.

Ziaei, N., J. H. Guy, S. A. Edwards, P. J. Blanchard, J. Ward, and D. Feuerstein. 2007. Effect of gender on factors affecting excreta dry matter content of broiler chickens. J. Appl. Poult. Res. 16:226-233. 